\title{
Comment
}

\section{The Boundaries of Legal Sociology*}

\author{
Donald J. Black $†$
}

I

Contemporary sociology of law is characterized by a confusion of science and policy. Its analysis proceeds in the disembodied tongue of science, in the language of "system," "structure," "pattern," and "orgnnization," or in the vocabulary of technique, of "needs," "functions," and "viability." Rarely does the language impart emotion, indignation, or even personal involvement on the part of the investigator. But while legal sociology is presented in this scientific language and scientific tone, normative considerations-the "ought" and the "just"-become subtly implicated.

Although legal sociologists ${ }^{1}$ typically criticize one another according to the usual scientific standards of methodological precision and theoretical validity, they frequently become preoccupied with the "policy implications" of their research. Occasionally, in assessing one another, they shed the mantle of science and become unabashedly political. Recently, for instance, a sociologist characterized the literiture of legal sociology as bourgeois, liberal, pluralist, and meliorist." He went on to argue that a more radical sociology is required, one that is "more critical in its premises and farther-reaching in its proposals."

- This paper has benefited from the reactions of several readers: Lcon Lipson, Maureen Mileski, David Trubek, and Stanton Wheeler. In March, 1972, an carly draft occasioned an informal seminar at the Center for the Study of Law and Society of the University of California at Berkeley. I thank the following participants in that scminar for helping me to sharpen my ideas: David Matza, Sheldon Messinger, Philippe Nonet, Jerome Skolnick, and Philip Selznick. Finally, I want to express appreciation to Henry M. Fields, a law student who first suggested that $I$ write this paper and then went on to contribute his considerable scholarly and editorial abilities to its preparation.

$\dagger$ Assistant Professor of Sociology and Lecturer in Law, Yale University.

1. In what follows I shall use the term "sociologists" as a matter of convention, though I intend to refer not only to Ph.D.'s in sociology but also to lawyers and political scien. tists and anyone else claiming to contribute to the scientific study of law as a social phic. nomenon. Most of my examples, however, derive from the scholarly literature cxplicitly labeled "sociology of law" and authored by academic sociologists.

2. Currie, Book Review, 81 YaLE L.J. 134 (1971), reviewing LAW AND THE BEHAvtohaL Sciences (L. Friedman \& S. Macaulay eds. 1969) and Society AND THE LeGal ORder (R. Schwartz \& J. Skolnick eds. 1970). These two collections of the legal sociology literature not only collect representative materials but also attempt to explain the relevance of the materials, thereby providing excellent examples of the style of discourse now dom. inating the field.

3. Id. at 145. A striking feature of Currie's review is that he pays little attention to the scientific adequacy of the work he criticizes. Instead, he focuses more upon the reform 
Whether liberal or radical, however, legal sociologists tend to share a style of discourse that deserves attention and comment.

It is my contention that a purely sociological approach to law should involve not an assessment of legal policy, but rather, a scientific analysis of legal life as a system of behavior. The ultimate contribution of this enterprise would be a general theory of law, a theory that would predict and explain every instance of legal behavior. While such a general theory may never be attained, efforts to achicve it should be central to the sociology of law. By contrast, the core problems of legal policymaking are problems of value. Such value considerations are as irrelevant to a sociology of law as they are to any other scientific theory of the empirical world.

Invoking the language of science and relying upon its aurn of respectability, sociologists move, in a special and almost imperceptible way, beyond science and deal with questions of legal evaluation. Because they confuse scientific questions with policy questions, they severely retard the development of their field. At best, they offer an applied sociology of law-at worst, sheer ideology.

After examining the type of discourse that passes for a sociology of law and noting its apparent shortcomings, I shall discuss more directly the nature and aims of a pure sociology of law.

II

With one phrase, legal effectiveness, we capture the major thematic concern of contemporary sociology of law. The wide range of work that revolves around the legal-effectiveness theme displays a common strategy of problem formulation, namely a comparison of legal reality to a legal ideal of some kind. Typically a gap is shown between lawin-action and law-in-theory. Often the sociologist then goes on to suggest how the reality might be brought closer to the ideal. Law is regarded as ineffective and in need of reform owing to the disparity between the legal reality and the ideal.t

Legal-effectiveness studies differ from one another, however, in the kinds of legal ideals against which their findings are measured. At one

implications of the existing work and condemns it on political rather than methodological or theoretical grounds. Thus, while he suggests that the work could greatly benefit from the perspectives of Marxian scholars, he fails to show that the Marxian approach to law has a superior explanatory power.

4. Because research in legal sociology consistently shows these disparities, the ficld has become identified with debunkery and the unmasking of law. In legal scholarship this debunking spirit goes back to the legal realism movement which has haunted Ameriean law schools since it emerged around the turn of the century. Mluch legal sociology, then. is a new legal realism, appearing in the prudent garb of social science, armed with sophisticated research methods, new language, and abstract theorctical constructs. 
extreme are "impact studies" that compare reality to legal ideals with a very plain and specific operational meaning. Here the legal meas. uring rod is likely to be a statute whose purpose is rather clearly discernible or a judicial decision unambiguously declarative of a specific policy. The Miranda decision, for example, requiring the police to apprise suspects of their legal rights before conducting an incustody interrogation, has a core meaning about which consensus is quite high. ${ }^{5}$ Soon after Miranda was handed down by the Supreme Court, research was initiated to evaluate the degree of police compliance with the decision. ${ }^{6}$ When the core meaning of a decision thus is clear, this type of research can be expected to show whether or not a decision has, in fact, been implemented.

Sociologists, however, may launch these implementation studies where legislation or judicial opinion is considerably more ambiguous than in Miranda. In such instances, the "impact" may be difficult to measure. What must be done, for example, to implement In re Gaull?" Though it is generally recognized that Gault guarantees to juvenile suspects constitutional rights previously accorded only to adults, the extent of these juvenile rights is not at all clear. ${ }^{8}$ Hence it becomes difficult, perhaps impossible, to identify the degree to which Gault has been implemented. ${ }^{9}$

5. Miranda v. Arizona, 384 U.S. 436 (1966). Although there may be some disagrecencut as to the peripheral meanings of "custody" and "interrogation" (see, e.g." Mathis v. United States, 391 U.S. 1 (1968); Orozco v. Texas, 394 U.S. 324 (1969)), there is little doubt that a suspect under arrest in a police station who is probingly questioncd about his in. volvement in a crime is both in custody and under interrogation as these concepts are used by the Court. Moreover, no question remains as to the required content of an appris. ing of rights. 384 U.S. at 478-79. Yet, there may even be disagrecenent as to what consti. tutes an "adequate" and "effective" apprising of rights. Id. at 467 . Compare Unitcd States v. Fox, 403 F.2d 97 (2d Cir. 1968), with State v. Renfrew, 280 Minn. 276, 159 N.W.2d 111 (1968). For example, would a police procedure of giving the suspect a preprinted card listing his rights meet the requirement of an adequate and effective apprisal? Would that procedure meet the Miranda test if the suspect were illiterate?

6. See, e.g., Project, Interrogations in New Haven: The Impact of Miranda, 76 YaL: L.J. 1519 (1967).

7. 387 U.S. 1 (1967).

8. See generally Foster, Notice and "Fair Procedure": Revolution or Simple Revision?, in Gault, WHAT Now fOR THE JUVEnile Court? 51 (V. Nordin ed. 1968). For cxamples of judicial conflict in the applicability of specific rights, compare: (1) Stanley v. Peyton, 292 F. Supp. 213 (W.D. Va. 1968), cert. denied, 400 U.S. 828 (1970) (dictum) and State V. Acuna, 78 N.MI. 119, 428 P.2d 658 (1967), with Steinhauer v. State, 206 So.2d 25 (Fla. Dist. Ct. App. 1967), quashed and remanded on other grounds, 216 So.2d 214 (1968), cert. denicd, 808 U.S. 914 (1970) (Douglas, J., dissenting on denial of cert.) (right to counscl at waiver of juvenile court jurisdiction hearing); (2) In re Fletcher, 251 Md. 520, 248 A.2d 364 (1968), cert. denied, 396 U.S. 852 (1969), with In re D., 30 App. Div. 2d 183, 290 N.Y.S.2d 935 (1968) (necessity of giving Miranda warnings to both juvenile and parents at pre-trial custodial interrogation); (3) In re Wylie, 231 A.2d 81 (D.C. Ct. App. 1967), with In re Urbasek, 38 Ill.2d 535, 232 N.E.2d 716 (1967) (right to standard of proof beyond a reasonable doubt).

9. See, e.g., Lefstein, Stapleton, \& Teitelbaum, In Search of Juvenile Justice: Gault and its Implementation 3 L. \& Soc. REv. 491 (1969), in which these problems of opcrationalizat. tion are evident. 
Finally, the sociologist may attempt to compare legal reality to an ideal grounded in neither statutory nor case law. Here the investigator assesses his empirical materials against standards of justice such as "the rule of law," "arbitrariness," "legality," or a concept of "due process" not explicitly anchored in the due process clause of the Constitution. Jerome Skolnick, for instance, asserts that the police employ the informer system in narcotics enforcement "irrespective of the constraints embodied in principles of due process." 10 But there is no indication of where Skolnick locates these principles. Presumably he realizes that no court in the United States has declared the practice illegal, and there is no reason to think such a decision is likely in the near future. ${ }^{11}$ In another study, Skolnick investigates plea-bargaining in the courtroom, concluding that the cooperation underlying this practice "deviates" from some unarticulated adversarial ideal.12 Similarly, Leon Mayhew, in arguing that the Massachusetts Commission Against Discrimination failed to define discrimination adequately and thereby ignored much illegal conduct, provides neither a legal argument nor an empirical referent for his interpretation of the Commission's proper mission. ${ }^{13}$ In short, then, some studies in legal sociology seem to move beyond the law when they measure legal reality against an ideal.

At its most useful, legal-effectiveness research may be valuable to people in a position to reform the legal order. In this sense it consists of studies in applied sociology of law. This would appear to be particularly true of those investigations that relate empirical findings to legal ideals which are clearly expressed in the written law. Such research might provide legal reformers with a kind of leverage for change, though the mere evidence of a gap between law-in-action and law-in-theory would not in itself overwhelm all resistance to change.

10. J. Skolnick, Justice Without Trial 138 (1966).

11. Much less than viewing the use of informers as a violation of constitutional safeguards, the Supreme Court has refused even to require that an informer's identity be revealed. Specifically, police reliance upon anonymous informants to provide the requisite information for probable cause to sustain an arrest or search warrant has been held not to violate either the Fourth Amendment or due process clausc. See AICCray v. Illinois, 386 U.S. 300 (1967); Draper v. United States, 358 U.S. 307 (1959). Information supplied by an unnamed informer of apparent reliability under certain circumstances may provide sufficient cause for a search without a warrant. Adams v. Williams, 10 U.S.L.W. 4724 (U.S. June 12, 1972). But if the police utilize an informant as a participant in an illegal narcotics transaction, even where there is no question of entrapment the government will be required to disclose the identity of the informant at trial when such disclosure may be "relevant and helpful to the accused's defense." The failure to disclose in this context would violate due process. Roviaro v. United States, 353 U.S. 53 (1957).

12. Skolnick, Social Control in the Adversary System, $11 \mathrm{~J}$. Cosfuct Resolutiox 52 (1967).

13. L. Mayhew, Law and Equal Opportunity (1969), revieued, Black, Book Review, 40 Soc. Inquiry 179 (1970). See Mayhew, Teleology and Values in the Social System: Reply to Donald J. Black, 40 Soc. INQuiry 182 (1970). 
Who can imagine a study, after all, that would not discover such a gap? Little is more predictable about the law than that these gaps exist.

However, legal-effectiveness research sometimes moves beyond ap. plied sociology. When legal reality is compared to an ideal with no identifiable empirical referent, such as "the rule of law" or "duc process," the investigator may inadvertently implant his personal ideals as the society's legal ideals. At this point social science ceases and advocacy begins. The value of legal-effectiveness research of this kind is bound to be precarious, for it involves, perhaps unwittingly, moral judgment at the very point where it promises scientific analysis.

\section{III}

As I have described it, the sociology of law significantly resembles a broader style of thought that has come to be known as technocratic thought, ${ }^{14}$ or, to use an earlier term, scientism. In the technocratic world-view, every problem-factual, moral, political, or legal-reduces to a question of technique. A good technique is one that works, and what works can be learned through science. Any problem that cannot be solved in this way is no problem at all, hardly worthy of our atten. tion. In theory, moreover, every problem can be solved if only the appropriate expertise is applied to it. Among the key words in the technocratic vocabulary are efficiency and, one I noted earlier, effectiveness. It is a style of thought in some respects akin to pragmatism, but it is a pragmatism with unstated goals, a search for the most rational way to go somewhere that is never clearly specified. Rather, we must infer what these goals are, and that is how some technocratic approaches come to be known as liberal and bourgeois, others as radical and critical. Technocrats do not make political arguments in the usual sense; they do not moralize. They simply want to get the job done.

The technocratic style dominates much discussion of social con. troversy at the higher reaches of American life. We are given to understand that scientific research will reveal whether marijuana should be legalized, that the Vietnam War was a miscalculation, and that eco. nomic analysis will determine the most "rational" tax program. The new nations of Africa and Asia are studied to determine what their modernization "requires." Riots, violence, and pornography give rise to government study commissions and research grants for the universities. Moral problems of every sort are translated into problems of

14. For a recent discussion of technocratic thought, see T. Roszak, THE MakiNG OF A Counter Culture 5-22 (1969). 
knowledge and science, of know-how. To discuss the criminal in the moral terms of right and wrong comes to be seen as primitive and unschooled; medical terminology is introduced into the discussion of the treatment of criminal offenders. In the name of science and progress, what was once seen as evil is studied and treated, not condemned.

The logic of this technocratic mentality has helped to catapult sociology to a position of some prominence in these times of rapid social change and conflict. Sociology, it is thought, will point the way to solutions to the many problems before us. The sociologists themselves have shown little reluctance to accept this responsibility. The typical sociologist knows almost nothing about moral or social philosophy, but if public policy is no more than a matter of scientific technique, why should he? In a technocratic era, moral philosophy is an oddity in the real world of action, a quaint remnant of the nineteenth century, something for the undergraduates.

\section{IV}

Law can be seen as a thing like any other in the empirical world. It is crucial to be clear that from a sociological standpoint, law consists in observable acts, not in rules as the concept of rule or norm is employed in both the literature of jurisprudence and in every-day legal language. ${ }^{15}$ From a sociological point of view, law is not what lawyers regard as binding or obligatory precepts, but rather, for example, the observable dispositions of judges, policemen, prosecutors, or administrative officials. ${ }^{16} \mathrm{Law}$ is like any other thing in the sense that it is as amenable to the scientific method as any other aspect of reality. No intellectual apparatus peculiar to the study of law is required. At the same time, a social science of law true to positivism, the conventional theory of science, cannot escape the limitations inherent in scientific thought itself.17 Perhaps a word should be said about these limitations.

15. Hence this sociological concept of law is very different from and not logically incompatible with the legal positivism of Hans Kelsen and his "pure theory of law:" See, e.g., H. Kelsen, General Theory of Law and State (1945). Similarly, to take another wellknown example, a sociological approach does not conflict with the rule-oriented juris. prudence of H.L.A. Hart in THE CoNcert OF LAI (1961).

At the level of social life in its narrow sense, law is bchavior and nothing more. If the concept of rule or norm is used in a sociological analysis, it should always refer 10 a behavioral pattern of some kind. See, e.g., E. Dukhueis, The Determination of Mforal Facts, in Sociology and Philosophy 35-62 (D.F. Pocock transl. 1953).

16. At a later point, I shall propose a sociological definition of law. See p. 1096 infra.

17. A good introduction to positivism is L. KolakowskI, THe Alienatios of Reason: A History of Positivist Thought (N. Guterman transl. 1968). 
Within the tradition of positivist philosophy, three basic principles of scientific knowledge can be noted. First, science can know only phenomena and never essences. ${ }^{18}$ The quest for the one correct concept of law or for anything else "distinctively legal" is therefore inherently unscientific. ${ }^{10}$ The essence of law is a problem for jurisprudence, not science. Second, every scientific idea requires a concrete empirical referent of some kind.20 A science can only order experience, and has no way of gaining access to non-empirical domains of knowledge. Accordingly, insofar as such ideals as justice, the rule of law, and due process are without a grounding in experience, they have no place in the sociology of law. Third, value judgments cannot be discovered in the empirical world and for that reason are without cognitive meaning in science. ${ }^{21}$

It is for this last reason that science knows nothing and can know nothing about the effectiveness of law. Science is incapable of an evaluation of the reality it confronts. To measure the effectiveness of law or of anything else for that matter, we must import standards of value that are foreign to science. ${ }^{22}$ What is disturbing about the contemporary literature on legal effectiveness then is not that it evaluates law, ${ }^{23}$ but rather, that its evaluations and proposals are presented as

18. This has been called the principle of phenomenalism. See id. at 3.4.

19. Philip Selznick, one of the most ambitious and influential students of legal effec. tiveness, considers the "cardinal weakness" of the sociological approach to law to bc its "failure to offer a theory of the distinctively legal." Selznick, The Sociology of Law, 9 INTERNATIONAL ENCYCLOPEDIA OF THE SOCIAL SCIENCES 51 (D.L. Sills cd. 1968).

20. This is the principle of nominalism. See Kolakowski, supra note 17, at 5.7.

21. Id. at 7-8. Some legal sociologists are willing to tolerate an obfuscation of factual and normative discourse. Selznick, for instance, while conceding that the separation of fact and value has some merit, nevertheless suggests that this distinction is meant for "unsophisticated minds." We must, he continues, unlearn this "casy and reassuring" formula from our "intellectual youth." Selznick finds a natural-law approach more appro. priate for the mature thinker. Selznick, Sociology and Natural Law, 6 NATURAL L.F. 86 (1961).

22. This does not say that scientific studies of legal effectiveness are impossible. As long as a social goal is introduced into the analysis and is adequately defined for purposes of the investigation, the study of effectiveness is perfectly feasible. Such applicd science can be as rigorously conducted as any other research. C $f$. pp. 1089.90 supra.

23. As a rule I do not personally find the policy criticisms and proposals of legal sociologists to be particularly objectionable, the exception being those proposals that increase the power of the government to intervene in citizens' lives. Thus, for instance, I find the therapeutic approach to criminal offenders a frightening advance of an already too powerful criminal justice system. In fact, I align myself more broadly and preciscly in the philosophical tradition of anarchism. For me, the validity of law is at all times contingent upon my own assessment of its moral validity, and thus I recognize no a priori legitimacy in the rule of law. For a brief introduction to this political cthic, sce R. WotrF, IN DEFENCE OF ANARCHISM (1970).

I would add that the students of legal effectiveness I am discussing are, politically speaking, the elite of our society, however critical of the legal process they may secm. Indeed, the government often finances their research on its own effectiveness. It is my view that the confusion of fact and value operates as a form of mystification that helps to keep the established order intact. Nevertheless, I do not wish to use my status as at scientist to promote my political philosophy. See M. WEDER, From MAX WeuEr: EssAYS iN SocroLocy $129-56$ (H.H. Gerth \& C.W. Mills transl. and eds. 1958). 
scientific findings. Far from denying this confusion, Philip Selznick ${ }^{24}$ has gone so far in the opposite direction as to claim that "nothing we know today precludes an effort to define 'ends proper to man's nature' and to discover objective standards of moral judgment."25

Legal sociologists involved in the study of effectiveness have thus come to advance a conception of scientific criticism of law. This is illogical; it is a contradiction in terms.

It is apparent by now that my critique of contemporary legal sociology is premised on the notion that sociology is a scientific enterprise and, as such, can be distinguished from moral philosophy, jurisprudence, or any other normatively oriented study-in other words, that the study of fact can be distinguished from the study of value. This is not to say that I am unaware of the criticisms that have been levied against a purely value-free social science. But while accepting these criticisms, I cannot understand the conclusion that the effort to develop an objective science of man should be abandoned.

It is important to understand precisely how values become involved in social science. One widely recognized intrusion of values occurs at the first stage of scientific inquiry: the choice of the problem for study. The values of the investigator may determine, for example, whether he selects a problem with great relevance for public policy or one of wholly academic interest. This intrusion of values was long ago noted by Max Weber, perhaps the most illustrious proponent of value-free sociology. Weber contended that the role of values in the choice of a problem is unavoidable and should be faced squarely, but he insisted that the problem, once selected, could and should be pursued "non-evaluatively."

But I would go further than Weber and grant that these value orientations may bias the analysis of the problem as well as its selection. Though various methodological techniques have been developed to minimize the effects of these biases, good social science still requires a disciplined disengagement on the part of the investigator-so disciplined, in fact, that it may rarely be achieved. Various arguments can be made to the effect that bias is built into social science at its very foundations. For example, the claim has been made that every social science study necessarily implicates the investigator in the perspective of an actual hierarchical position, seeing social life from

24. See note 19 supra.

25. Selznick, supra note 21 , at 93.94 .

26. See M. Weber, The Methodolocy of the Sociat Sciesces $21-22$ (E.A. Shils \& H.A. Finch transls. 1949). For a direct attack on Weber's approach to these questions, see Gouldner, Anti-Minotaur: The Myth of a Value-Free Sociology, 9 Soc. I'nonleass 199 (1962). 
either the social top or the bottom, and is therefore inherently biased. ${ }^{27}$ For purposes of discussion I grant even this. Similarly it is arguable that all social science is, beyond science, a form of ideology, if only because it is by its nature an instance of social behavior subject to the scrutiny of the very discipline of which it is a part. Sociology, that is, can be analyzed sociologically. Sociology does not occur in a vacuum and is undoubtedly influenced by social forces. Accordingly, sociology may be viewed as ideology supporting either the defenders of the status quo or their opponents. ${ }^{28}$

Finally, because much social science can be interpreted in an ideo. logical framework, its theories and findings can be used as weapons in the arena of public policymaking. The polemical impact of social science may be particularly great at this historical moment, given the enormous prestige of science in modern society. Not only do these theories and findings feed into existing policy debates, but they also can stimulate controversy and change by drawing attention to empirical situations that might otherwise be unknown or ignored by policymakers and social critics. Thus social science performs-willingly or not-an intelligence function in the political process. ${ }^{20}$ Because of such political ramifications, the argument has been put forward that the sociologist remains responsible for the consequences of his work. Only by making an explicit moral commitment can the social scientist hope to protect himself and others from the unintended consequences of his work. ${ }^{30}$ It is apparent that social science resonates into the realm of ideology, thereby raising serious questions about the scholar's responsibilities to his fellow man.

In several senses, then, values enter into the activity of social science. While values may play a similar role in science of all kinds, it can at least be admitted that their role is especially visible and dramatic when man is studying himself. Values may be all the more prominent in the

27. Becker, Whose Side Are We On?, 14 Soc. Problems 239 (1967).

28. This is a major theme of a recent critique of sociological thcory. See A. GouLdNER, The Cominc Crisis of Western Sociology (1970).

29. It should be clear that the policy impact of science is never direct but is always mediated by normative analysis, whether explicit or implicit. Policy cannot be deduced from scientific propositions alone. All of this is dramatically illustrated by the relation between the Marxian theory and public policy. Surely no theory of social science has had more impact upon the world. It has been an important weapon in idcological debate, and it has alerted policymakers and the public to the situation of the working class and the role of class conflict in social change. Yet as a scientific theory the Marxian analysis of society and history has no logical implications for political action. Without passing judy. ment upon the exploitation and growing misery of the proletariat, one could just as well sit back passively and watch history unfold as join the revolution. Both responses are logically independent of the theory.

30. R. DAHRENDORF, Values and Social Science: The Value Dispute in Perspective, in ESSAYS IN THE THEORY OF SOCIETY 17 (1968). 
study of man's moral life, of which legal sociology is one branch. The major arguments against the possibility of a pure science of man, in short, seem to have some merit. ${ }^{31}$ But the crucial question is what all of this implies for the traditional distinction between fact and value. I say it implies nothing. In fact, much of the criticism of value-free sociology itself rests upon observable patterns of value impact upon social science and for that reason relies upon the fact-value distinction for its own validity.

We have seen that a social scientist may be affected by values in the choice of his problem and may be biased in his approach to it. Critics of a value-free social science assert that these psychological effects, along with the ideological character of social science when viewed as the object of analysis itself, undermine the validity of social science. But this is to confuse the origins and uses of a scientific statement with its validity. ${ }^{32}$ The fact that scientific statements are influenced by values does not make them value statements. The psychological and social influence of values on scientific inquiry has no logical implications for the validity of a scientific proposition. Its validity is determined only by empirical verification. A value statement, by contrast, is not subject to such a test. ${ }^{33} \mathrm{How}$, for example, is the following statement to be empirically verified: "Democratic process is an ultimate good"? The fact that we can distinguish between scientific propositions and such value statements is all we need to assert the possibility

31. Of course in this brief discussion I cannot begin to review the sizable literature on the subject. Perhaps I should note, however, one criticism of the value-neutral stratch; that bears directly on the study of law-one, moreover, that seems to me to be wholly without merit. This criticism asserts that the study of normative life, because it is normative, requires a partially normative approach on the part of the investigator if he is to comprehend its empirical character. The investigator must take the nomative view of the participants if he is to understand their normative behavior. Sclznick, for instance, suggests that the sociologist should make an "assessment" of the degree to which a normative system reaches an ideal "from the standpoint of the normative system being studied" though "the student of a normative system need not have any personal commitment to the desirability of that system." Selznick, supre note 21, at 88. In the study of law, therefore, it seems we must include an assessment of legal reality in terms of the ideals of the legal system we study.

In my view this argument incorrectly assumes that such normative ideals can be identified at a wholly empirical level. I do not believe, for cxample, that the degree of conformity of law with, let us say, a constitutional ideal, is a wholly empirical question. The nature of the ideal is itself a normative question, a question of normative interpretation. In the study of law such interpretation is the heart of legal scholarship, and from a positivist standpoint that activity is, at its core, normative rather than scientific. It advances an "ought" as the proper measure of reality, and it does not matter whether or not the interpreter himself subscribes to the "ought." It remains an unavoidably normative judgment. In effect, then, Selznick's view is that in order 10 understand normative life we must be normative. This view, I believe, is a non sequitur.

32. See Dahrendorf, supra note 30, at 9-10.

33. Although not subject to empirical verification, a value statement may be subject to other criteria such as its logical status in relation to a more general axiological principle. 
of social science. In short, values may affect social science profoundly, but that is no reason to abandon the enterprise. ${ }^{34}$

\section{$\mathrm{V}$}

The proper concern of legal sociology should be the development of a general theory of law. A general theory involves several key ele. ments that may not at first be obvious. To say that a theory of law is general means that it seeks to order law wherever it is found. It seeks to discover the principles and mechanisms that predict empirical patterns of law, whether these patterns occur in this day or the past, regardless of the substantive area of law involved and regardless of the society. By contrast, the contemporary study of law is ideographic, very concrete and historical. Legal scholars tend to rebel at the suggestion of a general theory of their subject matter. Nevertheless, unless we seek generality in our study of law, we abandon hope for a serious sociology of law.

If the sweep of legal sociology is to be this broad, a correspondingly broad concept of law is required. I like to define law simply as governmental social control. ${ }^{35}$ This is one possibility among many consistent with a positivist strategy. It is a concept easily employed in cross-societal analysis, encompassing any act by a political body that concerns the definition of social order or its defense. At the same time it excludes such forms of social control as popular morality and bureaucratic rules in private organizations. It is more inclusive than an American lawyer might deem proper, but more selective than anthro.

34. My critique of contemporary legal sociology arises from a very conventional conception of scientific method, a conception associated with the broader tradition of posl. tivist thought. I have not made and do not intend to make a philosophical defense of this tradition. I wish only to advocate a sociology of law true to basic positivist prin. ciples as they have come to be understood in the history of the philosophy of science.

35. I mention this only as a means of delineating the subject matter of legal sociology. A definition of the subject matter is a prerequisite to any scientific inquiry. Just as a physicist must first define motion before he can describe its characteristics, a sociologist of religion, for example, must first define the pattern of social behavior that constitutes religion before he can proceed with his research. This does not mean that there is only one proper definition. Law itself has been defined non-normatively in a varicty of ways. See, e.g., M. Weber, The Theory of Social and Economic Organizhtion 127 (T. Parsons ed. \& transl. 1964):

An order will be called law when conformity with it is upheld by the probability that deviant action will be met by physical or psychic sanctions aimed to compel conformity or to punish disobedience, and applied by a group of men especially empowered to carry out this function.

I have chosen "governmental social control" as a definition of law for the reasons that follow in the text. I should add, however, that for me the choice of a particular socio. logical concept of law is not at all critical to my larger aim, since my ultimate interest goes beyond law per se to all forms of social control. For me, the stidy of law is pre. liminary and subordinate to the more general study of social control systems of all kinds. Therefore, if my concept of law is too narrow or too broad it does not matter theo. retically, since it will in any case be relevant to a sociology of social control. 
pological concepts which treat law as synonymous with normative life and dispute settlement of every description, governmental or otherwise. If we are to have a manageable subject matter, our concept must construe law as one among a larger array of social control systems. And if we are to have a strategically detached approach, our concept must be value neutral. We need a theoretical structure applicable to the law of the Nazis as well as American law, to revolutionary law and colonial law as well as the cumbersome law of traditional China. What do these systems share, and how can we explain the differences among them?

Ultimately a theory is known and judged by its statements about the world. These statements both guide and follow empirical research. They propose uniformities in the relation between one part of reality and another. Thus a general theory of law is addressed to the relation between law and other aspects of social life, including, for instance, other forms of social control, social stratification, the division of labor, social integration, group size, and the structure and substance of social networks. At the moment we have only a small inventory of theoretical statements, or propositions, of this kind. The relevant literature is sparse, and many of our leads must come from the classic works of Maine, ${ }^{36}$ Durkheim, ${ }^{37}$ Weber, ${ }^{38}$ Ehrlich, ${ }^{30}$ Pound, ${ }^{40}$ and the like. Marx, too, should not be forgotten, though he gave law only passing attention. ${ }^{41}$ Apart from classical sociology and comparative jurisprudence, anthropological literature, notably the work of such scholars as Malinowski, 42 Hoebel, $\$ 3$ Gluckman, 44 Bohannan, 45 and Nader, 40

36. See, e.g., ANCient LAW (1861); Village-Communtres in the East and W'est (1871).

37. The Division of Labor in Society (G. Simpson transl. 1933); Professional. Etilics ANd Crvic Morals (C. Brookfield transl. 1957); Two Laus of Penal Evolution (M. Mileski transl. 1971) (available in my files).

38. Max WEBER ON LAw IN Economy aNd SOciety (MI. Rhcinstein cd., E. Shils \& M. Rheinstein transls. 1951).

39. Fundamental Principles of the Sociology of Law (W. Moll transl. 1930).

40. E.g., Social Control Throvgh Law (19:12); The Limits of Effective Legal Action, 27 INT"L J. ETHics 150 (1917); $A$ Survey of Social Interests, 57 HARv. L. REv. I (1943).

41. Marx did, however, inspire some interesting sociological work on law. Sec, e.g, K. Renner, The Institutions of Private Law and Their Social Functions (O. KahnFreund ed., A. Schwartzchild transl. 1949); Pashukanis, The General Theory of Law and Marxism, in Soviet Legal Philosopiy 111 (H. Babb transl. 195l).

42. The standard work is Crime and Custom in Savage Society (1920). This study is considered the first ethnography of law.

43. The Law of Primitive Man (1954); K. Lleweldsin \& E. Hoenel, The Chevesie

Way: Conflict and Case Law in Primitive Jurisprudence (1941).

44. See, e.g., The Judicial Process AMong the B.arotse of Nortilers Rhodesia (1955). Gluckman provides a useful overview of legal anthropology in PoLrTic, LAW AND RITUAL in TRIBAL Society (1965).

45. Justice ANd Judgment Amonc the Tiv (1957); The Differing Realms of the Law, in The EthNography of LAw 33 (1965) (supplement to 67 AM. ANtrirorologist 39 (1965)) 46. E.g., An Analysis of Zapotec Law Cases, 3 Etrixolocy 401 (1964); Choices in Legal Procedure: Shia Moslem and Mexican Zapotec, 67 AM. ANTIRopolocist 391 (1965). 
has contributed more than sociology to a general theory of law. Contemporary sociologists tend to limit their attention to the American legal system, and even there, disproportionate emphasis is given the criminal justice system. Rarely do they compare American law to governmental social control in other societies; yet if legal sociology is not comparative, its conclusions will inevitably be time-bound and ethno. centric.

This is not to suggest that American criminal justice is unworthy of study. But one must address problems at a higher level of generality, thereby contributing to and benefiting from scholarship in other realms of law. If we investigate the police, for example, our fundamental interest as sociologists must be in what police work can teach us about law, generically understood, and we must bring to a study of the police whatever we know about other forms of legal life. From my standpoint, in other words, the major shortcoming of most socio. logical literature on the police is that it concerns the police alone, instead of treating police behavior as an instance of law. Often sociolo. gists occupy themselves with the unique world of the policeman, his attitudes, hopes and fears, his relations with his fellow officers, his social isolation in the wider community-in brief, with the "human" dimensions of police work. ${ }^{47}$ Insofar as such studies rise above descriptive journalism or ethnography, then, they tend to focus upon the psychology of the policeman on his day-to-day round. Yet from a purely sociological point of view it is not important to know that policemen are, after all, "human" or to know how their minds work. A pure sociology of law does not study humans in the usual sense. It studies law as a system of behavior. ${ }^{48}$ Taken in this sense, law feels nothing. It has no joy or sorrow or wonderment. Scientifically conceived as a social reality in its own right, law is no more human than a molecular structure. It has no nationality, no mind, and no ends proper to its nature.

I do not mean to criticize categorically the rather impressive body of police research that has accumulated in recent years, but only to suggest that its contribution to the sociology of law is limited. We must give up the notion that the sociology of law embraces any and all forms of empirical research relating to the legal system. A scientific discipline is defined by its theoretical mission, by what it tries to ex-

47. E.g., Sholnick, supra note 10; W. WeStley, VIOLENCE ANd THE POLICE: $\Lambda$ Socio. logical Study of Law, Custom, ANd Morality (1970); Bittner, The Police on Shid.Rout: A Study of Peace-Keeping, 32 AM. Soc. REv. 699 (1967); Werthman and Piliavin, Gang Members and the Police, in The Police: Six Soctologicsl Essays 56 (D. Bordua cd. 1967).

48. See p. 1091 supra. 
plain, not by its sources of data. Thus, research on the human body may contribute to any of a variety of disciplines-biochemistry, genetics, endocrinology, physiological psychology, or whatever. The same is true of research on law or the police. Accordingly, a study of the police contributes to legal sociology only if it provides insights into legal behavior, its empirical profile, the social conditions under which it occurs, and its social implications. I am not saying that every sociologist must be a theorist, but only that any sociologist who does research on a legal topic without knowing, roughly, its theoretical relevance does so at his peril.

Police research should tell us something about the social control function of the police: What legal matters do they handle? How do they come to deal with those matters? What are the principles according to which they process their cases? Ideally a study would also tell us how police behavior resembles other known patterns of legal behavior and how it differs. We know, for example, that the police make arrests relatively infrequently when some other form of social control is available in the situation. Thus, they rarely make an arrest when one family member criminally offends another, a situation where other means of social pressure typically are at hand, whereas the same offense committed by one stranger against another is very apt to result in arrest. ${ }^{49}$ This pattern of legal behavior is known to have analogues in a wide variety of legal settings, in civil as well as criminal cases, in the invocation of law as well as its application, in many countries and historical periods, and even in the evolution of law itself..50 We may state the pattern as a theoretical proposition: Law tends to become implicated in social life to the degree that other forms of social control are weak or unavailable. ${ }^{51}$ Hence, what we discover in the behavior of policemen turns out to be simply an instance of a much more general pattern in the conditions under which the law acts upon social life. We thereby add systematically to existing knowledge of this pattern, and, what is more, we can explain the behavior of the police, since it can be predicted and deduced from a more general proposition about law. ${ }^{52}$ If the likelihood of legal control is greater where other forms of social control are absent, it follows that the police are more likely to arrest a stranger who, let us say, assaults a stranger than a son who assaults his father. To be able to explain something so mundane

49. Black, The Social Organization of Arrest, 23 SrAN. L. REv. 1087, 1107 (1971).

50. Id. at 1107-08 nn.30-34.

51. Id. at 1108 .

52. For a discussion of this type of explanation, see R. Bratriwitre, Scientific Explanation: A Study of the function of Tueory, Prorabiztr and Law in Saesce (19j3). 
and microscopic as behavior in a police encounter with the same proposition that we use to explain the historical emergence of law itself is exciting and encouraging. It provides a glimpse of general theory in action. This kind of theoretical structure is built up and elaborated over time through a process of give-and-take between data and tentative propositions stated at a high level of abstraction. It is the classical pattern of scientific advance, and I cannot see why the sociology of law should be any less ambitious or any less rigorous.

\section{VI}

We should be clear about the relation between sociological and legal scholarship. There is, properly speaking, no conflict of professional jurisdiction between the two. A legal problem is a problem of value and is forever beyond the reach of sociology. Jurisdictional conflict arises only when the sociologist makes policy recommendations in the name of science: In matters of legal policy, the lawyer must rely on his own wits.

But a more significant matter than jurisdictional clarity is the relation between pure and applied sociology of law. My view, hardly novel, is that the quality of applied science depends upon the quality of pure science. Just as major advances in mechanical and chemical engineering have been made possible by theoretical formulations in pure physics and chemistry, so legal engineering ultimately requires a general theory of how legal systems behave as natural phenomena. The case for a pure sociology of law does not rest solely on its social usefulness, but if utility is at issue, then in the long run the type of work I advocate is crucial. At present, applied sociology of law has little to apply. What more serious claim could be brought against it? 


\section{The Yale Law Journal}

Volume 81, Number 6, May 1972

\section{David M. Schulte Editor-in-Chief}

\section{Stephen R. Munzer}

Executive Editor
Thomas M. JoRde JOHN B. KUHNS JERRY L. STEgeL Article Editors

RALPH R. ARDITI Dean D. Aulick Michael J. BEAN Nangy Y. Bekavac Daniel J. Beller Richard A. BLOCK Richard Blumenthal ERIC J. BranfMaAN Michael J. Churgin Michael M. Conivay KathleEn M. DoggetT Peter H. Ehrenberg ROBERT W. FISHER ROgER W. Fonseca GaRY L. FonTANa BRUCE G. FreEdMaN Donald J. Friedman NANCY C. Garrison ROBERT E. GIPSON KENNETH M. GLAZIER Frederick T. GoldBERG Charles A. Goldmark
JEFFrey I. GLEkEL STEPHEN J. HADLEY ANDREW D. HURWITZ David H. KaYE ERIC R. NeISSER Note \& Comment Editors

Steven R. Gross Peter T. Grossi, Jr. HeNry B. HaNsMranN TIMOTHY S. HARDY FreDERICK K. HeLLER, Jr. CuRT A. Hessler PETER M. Hoffaran JAMES R. HUNTWORK STANLEY N. INGBER RANDALL K.C. KAU KENNETH M. KaUfMAN DANIEL J. KoRNSTEIN Eugene A. Ludivig JOSEPH M. MaLKIN ROBERT B. MANN Samuel H. Mays, Jr. JOHN B. OAKLEY NEIL H. O'DONNELL STEPHEN A. OXMAN Samuel T. Perkins Jay E. Powell
LAURENCE S. LUSTGARTEN

Comment \& Reviews Editor

Henry M. Fiecds

Managing Editor

Robert C. Pozen

LINDA L. RANDELL ROBERT S. RAYMAAR ROBERT B. REICH Peter L. Rossiter Michael L. SchLer Geoffrey B. Shields LESLIE N. SILVERAIAN ARTHUR J. SilversteIN Peter WV.SLY AviaMr SOIfER MARk I. Soler SidNEY H. STEIN Alexander R. Sussimas Robert M. Sussicas S. MIARK TULLER RICHARD J. UROW'SKY MARK L. TWEISSLER ALAN J. TWILENSKY JERALD L. WiLkERSON Charles L. Woltmanis JEFFREX I. ZUCKERILAN

Business Secretaries M. Olive Butterfield, Pamela Winlarott

\section{Student Contributors to This Issue}

John B. Oakley, The Ins and Outs of IATA: Improving the Role of the United States in the Regulation of Air Fares

Jay E. Powell, Admiralty Practice After Unification: Barnacles on the Procedural Hull

Robert E. Gipson, Advertising, Solicitation and the Professional Duty to Make Legal Counsel Available

Henry B. Hansmann, Piggyback Jurisdiction in the Proposed Federal Criminal Code 